(RESEARCH ARTICLE)

\title{
Effects of culture medium strength and antioxidants on adventitious bud multiplication, hyperhydricity and tissue browning of date palm cv. Aziza Bouzid
}

\author{
Saida Elmaataoui ${ }^{1}$, Mouaad Amine Mazri 1,*, Reda Meziani ${ }^{2}$ and Fatima Bouchiha 1 \\ ${ }^{1}$ Institut National de la Recherche Agronomique, CRRA-Marrakech, UR Agro-Biotechnologie, Laboratoire de \\ Biotechnologie Végétale, BP 533, Marrakech, Morocco \\ 2 Institut National de la Recherche Agronomique, CRRA-Errachidia, UR Systèmes Oasiens, Laboratoire National de Culture \\ des Tissus du Palmier Dattier, Avenue Moulay Ali Cherif, BP 2, Errachidia, Morocco.
}

Publication history: Received on 01 May 2020; revised on 11 May 2020; accepted on 13 May 2020

Article DOI: https://doi.org/10.30574/wjarr.2020.6.2.0137

\begin{abstract}
The effects of medium strength as well as different antioxidant types and concentrations on adventitious shoot bud multiplication, hyperhydricity and tissue browning of date palm cv. Aziza Bouzid were evaluated. Organogenic cultures of date palm cv. Aziza Bouzid were cultured on semi-solid Murashige and Skoog medium at half-strength (MS/2) or onethird-strength (MS/3), supplemented with $0.5 \mathrm{mg} / \mathrm{L} \mathrm{2-naphthoxyacetic} \mathrm{acid} \mathrm{(NOA),} 0.5 \mathrm{mg} / \mathrm{L}$ kinetin, and different concentrations of activated charcoal and polyvinylpyrrolidone (PVP). The findings of the present study showed that the use MS/3 media resulted in lower hyperhydricity rates than MS/2 media. Besides, activated charcoal significantly reduced tissue browning. The lowest rates of hyperhydricity (35\%) and tissue browning (20\%) were observed in MS/3 medium supplemented with $1.5 \mathrm{~g} / \mathrm{L}$ activated charcoal. Interestingly, this culture medium showed also the highest number of adventitious shoot buds per explant (35.20), with a significant difference with all the other media (25.5530.15 adventitious shoot buds per explant). Increasing the concentration of activated charcoal to $2 \mathrm{~g} / \mathrm{L}$ did not decreased the browning rate. The use of PVP alone showed tissue browning rates varying from 30 to $55 \%$ while combining PVP and activated charcoal showed browning percentages ranging from 20 to 30\%. Shoot elongation and rooting were successfully achieved and plantlet were acclimatized and showed normal growth and development under the greenhouse conditions.
\end{abstract}

Keywords: Date palm; Hyperhydricity; In vitro; Organogenesis; Regeneration; Tissue browning.

\section{Introduction}

Date palm is a multipurpose plant species widely cultivated in the Middle East and North Africa (MENA) region. It belongs to the family Arecaceae (Palmae). Date palm is an economically important species mainly cultivated for its delicious and nutritious fruits. However, it is also used to create favorable microclimate for agriculture and as shelter in the extreme conditions of desert. Besides, date palm plants are used to make paper and fibers and to manufacture handicraft products, thus contributing to the income of the inhabitants of the arid and semi-arid regions [1].

In Morocco, date palm is threatened by bayoud, a very dangerous wilt disease caused by the fungus Fusarium oxysporum f. sp. albedinis and that killed millions of date palm plants [2]. To date, the only way to fight bayoud and to preserve the best date palm genotypes is through rapid and large-scale propagation [3].

Date palm propagation can be achieved either conventionally by seeds or offshoots, or through in vitro culture techniques [4]. Propagation through seedlings cannot be used for the large-scale production of true-to-type plantlets, while propagation through offshoots is hampered by the limited number of offshoots produced by a date palm plant,

\footnotetext{
* Corresponding author: Mouaad Amine Mazri Email:m.a.mazri@gmail.com
} 
rooting difficulty and the risk of pathogen propagation [4]. In the recent years, propagation through tissue culture techniques has become the main method used for the rapid and large-scale production of date palm plantlets in many date producing countries [1].

Micropropagation of date palm is mainly achieved through direct organogenesis $[5,6]$ and indirect somatic embryogenesis $[7,8]$. The use of these two techniques is, up to date, the most efficient way for the commercial plant production of this species.

In Morocco, organogenesis is the preferred in vitro regeneration system for date palm since it allows the production of true-to-type plantlets, which is not always the case when somatic embryogenesis is used $[9,10,11,12]$. This regeneration process comprises the following steps: adventitious bud initiation, shoot bud multiplication, shoot elongation and rooting and finally plantlet acclimatization [13]. The development of an efficient regeneration system through organogenesis in date palm has direct applications in rapid and large-scale propagation of genotypes resistant to the bayoud disease $[9,13]$, and of those highly requested by the consumers $[14,15]$. However, plantlet regeneration through organogenesis may be hampered due to some physiological disorders such as hyperhydricity and tissue browning $[4,14]$.

Date palm organogenesis is influenced by numerous factors including the explant type, the medium components and culture conditions. Furthermore, in date palm, it is well known that regeneration through organogenesis is highly genotype-dependent [16]. Besides, optimizing the medium components is of extreme importance in order to limit the incidence of undesirable phenomena such as hyperhydricity and tissue browning.

In a previous work on date palm cv. Aziza Bouzid, we evaluated the effects of many auxin-cytokinin combinations and concentrations in order to find out the best one for efficient multiplication of adventitious buds. Unfortunately, high frequencies of tissue browning and hyperhydricity were observed [17]. Tissue browning is a physiological disorder encountered during date palm micropropagation $[14,18]$. It is caused by the high concentration of caffeoylshikimic acids in date palm explants and may cause important losses during the in vitro regeneration process [19]. To reduce the incidence of this phenomenon, activated charcoal and polyvinylpyrrolidone (PVP) have been widely used [6]. Hyperhydricity is another physiological disorder that causes explants in culture to become translucent and glassy. The incidence of hyperhydricity was correlated with high concentrations of ammonium, some plant growth regulators (PGRs) as well as the use of liquid media [14, 20].

The aim of the present study was to evaluate the effects of different concentrations of PVP and activated charcoal as well as the use of a culture medium with reduced salt concentrations on adventitious shoot bud multiplication and the incidence of tissue browning and hyperhydricity in date palm cv. Aziza Bouzid.

\section{Material and methods}

\subsection{Plant material}

Organogenic cultures of date palm cv. Aziza Bouzid, containing 3-4 adventitious buds induced according to the protocol described by Beauchesne et al. [21] were used in the present investigation.

\subsection{Experiments}

The organogenic cultures were cultured on the basal formulation of Murashige and Skoog medium [22], either at halfstrength (MS/2, consisting of MS/2 macro-elements, MS microelements and MS vitamins) or at one-third-strength (MS/3, consisting of MS/3 macro-elements, MS microelements and MS vitamins). The culture media were supplemented with $30 \mathrm{~g} / \mathrm{L}$ commercial granulated sugar, $8 \mathrm{~g} / \mathrm{L}$ agar, $0.5 \mathrm{mg} / \mathrm{L}$ 2-naphthoxyacetic acid (NOA) and $0.5 \mathrm{mg} / \mathrm{L}$ kinetin as suggested by Elmaataoui et al. [17], and different concentrations of activated charcoal and polyvinylpyrrolidone (PVP) as follows:

- $\quad$ CM1: MS $/ 2+0.5 \mathrm{mg} / \mathrm{L} \mathrm{NOA}+0.5 \mathrm{mg} / \mathrm{L}$ kinetin $+1.5 \mathrm{~g} / \mathrm{L} \mathrm{PVP}$

- $\quad \mathrm{CM} 2: \mathrm{MS} / 2+0.5 \mathrm{mg} / \mathrm{L} \mathrm{NOA}+0.5 \mathrm{mg} / \mathrm{L}$ kinetin $+2 \mathrm{~g} / \mathrm{L} \mathrm{PVP}$

- $\quad$ CM3: MS $/ 2+0.5 \mathrm{mg} / \mathrm{L} \mathrm{NOA}+0.5 \mathrm{mg} / \mathrm{L}$ kinetin $+1.5 \mathrm{~g} / \mathrm{L}$ activated charcoal

- $\quad$ CM4: MS $/ 2+0.5 \mathrm{mg} / \mathrm{L} \mathrm{NOA}+0.5 \mathrm{mg} / \mathrm{L}$ kinetin $+2 \mathrm{~g} / \mathrm{L}$ activated charcoal

- $\quad$ CM5: MS $/ 2+0.5 \mathrm{mg} / \mathrm{L} \mathrm{NOA}+0.5 \mathrm{mg} / \mathrm{L}$ kinetin $+0.75 \mathrm{~g} / \mathrm{L} \mathrm{PVP}+0.75 \mathrm{~g} / \mathrm{L}$ activated charcoal

- CM6: MS $/ 2+0.5 \mathrm{mg} / \mathrm{L} \mathrm{NOA}+0.5 \mathrm{mg} / \mathrm{L}$ kinetin $+1 \mathrm{~g} / \mathrm{L} \mathrm{PVP}+1 \mathrm{~g} / \mathrm{L}$ activated charcoal

- $\quad$ CM7: MS/3 + $0.5 \mathrm{mg} / \mathrm{L} \mathrm{NOA}+0.5 \mathrm{mg} / \mathrm{L}$ kinetin $+1.5 \mathrm{~g} / \mathrm{L} \mathrm{PVP}$ 
- CM8: MS/3 + $0.5 \mathrm{mg} / \mathrm{L} \mathrm{NOA}+0.5 \mathrm{mg} / \mathrm{L}$ kinetin $+2 \mathrm{~g} / \mathrm{L}$ PVP

- $\quad$ CM9: $\mathrm{MS} / 3+0.5 \mathrm{mg} / \mathrm{L} \mathrm{NOA}+0.5 \mathrm{mg} / \mathrm{L}$ kinetin $+1.5 \mathrm{~g} / \mathrm{L}$ activated charcoal

- $\quad$ CM10: MS $/ 3+0.5 \mathrm{mg} / \mathrm{L} \mathrm{NOA}+0.5 \mathrm{mg} / \mathrm{L}$ kinetin $+2 \mathrm{~g} / \mathrm{L}$ activated charcoal

- $\quad$ CM11: MS $/ 3+0.5 \mathrm{mg} / \mathrm{L} \mathrm{NOA}+0.5 \mathrm{mg} / \mathrm{L}$ kinetin $+0.75 \mathrm{~g} / \mathrm{L} \mathrm{PVP}+0.75 \mathrm{~g} / \mathrm{L}$ activated charcoal

- CM12: MS/3 + $0.5 \mathrm{mg} / \mathrm{L} \mathrm{NOA}+0.5 \mathrm{mg} / \mathrm{L}$ kinetin $+1 \mathrm{~g} / \mathrm{L} \mathrm{PVP}+1 \mathrm{~g} / \mathrm{L}$ activated charcoal

\subsection{Shoot development and plant acclimatization}

All adventitious shoot buds were singled out and transferred to PGR-free MS/2 medium for 3 months for elongation and rooting. After this period, the developed plants were transferred to ex vitro conditions according to the protocol used in our laboratory $[3,9]$.

\subsection{Culture conditions}

Prior to sterilization, the $\mathrm{pH}$ of the culture media was fixed to 5.7 by using $\mathrm{NaOH}$ and $\mathrm{HCl}$ solutions. For each treatment, two organogenic cultures were placed per jar containing $40 \mathrm{ml}$ of culture medium, and a total of 20 organogenic cultures were used. The organogenic cultures were transferred to the same fresh medium at 1-month intervals. All cultures were kept at a $16 \mathrm{~h}$ photoperiod and $25 \pm 1{ }^{\circ} \mathrm{C}$ temperature.

\subsection{Data collection and statistical analyses}

After 3 months of culture, the average number of adventitious shoot buds per explant, tissue browning percentage and intensity, and hyperhydricity percentage and intensity were recorded. Tissue browning and hyperhydricity intensities were visually estimated as low (+), moderate $(++)$ and high $(+++)$. Experiments were carried out as a completely randomized design and all date were subjected to ANOVA. Percentage data were arcsine transformed prior to analysis. The means were compared using the Student-Newman-Keuls (SNK) test at the 5\% significance. Collected data were analyzed by the SPSS software version 26 .

\section{Results and discussion}

In a previously published study by our group, we determined the optimal PGR combination for adventitious shoot bud multiplication of date palm cv. Aziza Bouzid [17]. However, high percentages of hyperhydricity and tissue browning were observed. Hyperhydricity and tissue browning are two major physiological disorders encountered during the in vitro multiplication of date palm. Tissue browning is caused by the high concentration of caffeoylshikimic acids in date palm explants while hyperhydricity generally occurs when explants are cultured on media containing high concentrations of ammonium nitrate [20]. These phenomena are able to cause considerable losses during the commercial production of date palm plants.

The findings of the present investigation showed that tissue browning rates ranged from 20 to 55\% (Table 1). The lowest tissue browning percentages were observed on media CM4, CM9, CM10 and CM12, all supplemented with activated charcoal at concentrations ranging from 1 to $2 \mathrm{~g} / \mathrm{L}$. Besides, there was no significant difference with the media CM6 and CM11, which showed a tissue browning percentage of 25\%. These two media were supplemented with the combination of PVP and activated charcoal at the same concentration: 0.75 or $1 \mathrm{~g} / \mathrm{L}$ each. On the other hand, the highest tissue browning percentages (50 and 55\%) were observed on CM1 and CM7 media, respectively. These two culture media were supplemented with $1.5 \mathrm{~g} / \mathrm{L}$ PVP. Regarding tissue browning intensity, almost all media showed low intensity. In fact, only CM7 medium that showed a moderate intensity of tissue browning. Based on our findings, we can conclude that activated charcoal has a more potent impact against tissue browning than PVP.

Reducing tissue browning of date palm explants is very important to improve the multiplication efficiency. In fact, this phenomenon may cause important losses during the regeneration process. Abohatem et al. [18] have suggested to reduce time between subcultures in order to reduce the tissue browning frequency while Mazri [14] advised against the use of thidiazuron since it was a causal factor of tissue browning in cv. Boufeggous. In the present study, we evaluated and compared the effects of PVP and activated charcoal against tissue browning.

Activated charcoal acts by adsorbing phenolic compounds and inhibiting the activity of polyphenol oxidase and peroxidase [23] while PVP adsorbs the toxic phenolic compounds accumulated in culture medium [19]. These two compounds have been used in many plant species to reduce tissue browning, including Rubus idaeus L. [24], Zingiber officinale Rosc. [25] and Curculigo latifolia Dryand [26]. 
Meziani et al. [6] have also evaluated the effects of PVP and activated charcoal in date palm cv. Mejhoul and found similar effect when they were used at the same concentration during the initiation phase. However, during the multiplication phase, PVP showed better results than activated charcoal, which is not consistent with our results. This is may be due to the genotype effect. In fact, it is well known that, in date palm, the requirements for optimal multiplication of shoot buds depend strongly on the genotype. By comparing the findings of the present study to those already published by our group where PVP were used at the concentration of $1 \mathrm{~g} / \mathrm{L}$ [17], we can conclude that the use of activated charcoal played an important role in reducing tissue browning from $50-75 \%$ to $20 \%$.

Table 1 Effect of medium strength, activated charcoal and PVP on adventitious bud multiplication, hyperhydricity and tissue browning of organogenic cultures of date palm cv. Aziza Bouzid.

\begin{tabular}{llllll}
\hline $\begin{array}{l}\text { Culture } \\
\text { medium }\end{array}$ & $\begin{array}{l}\text { Mean number } \\
\text { of } \\
\text { adventitious } \\
\text { buds per } \\
\text { explant }\end{array}$ & $\begin{array}{l}\text { Hyperhydricity } \\
(\%)\end{array}$ & $\begin{array}{l}\text { Intensity of } \\
\text { hyperhydricity }\end{array}$ & $\begin{array}{l}\text { Tissue } \\
\text { browning (\%) }\end{array}$ & $\begin{array}{l}\text { Intensity } \\
\text { of tissue } \\
\text { browning }\end{array}$ \\
& $30.15 \pm 4.68 \mathrm{a}$ & $45 \pm 51.04 \mathrm{ab}$ & + & $50 \pm 51.30 \mathrm{~b}$ & + \\
\hline CM1 & $28.20 \pm 3.68 \mathrm{a}$ & $50 \pm 51.30 \mathrm{~b}$ & + & $45 \pm 51.04 \mathrm{ab}$ & + \\
CM2 & $29.70 \pm 4.55 \mathrm{a}$ & $50 \pm 51.30 \mathrm{~b}$ & + & $30 \pm 47.02 \mathrm{ab}$ & + \\
CM3 & $29.05 \pm 4.81 \mathrm{a}$ & $50 \pm 51.30 \mathrm{~b}$ & + & $20 \pm 41.04 \mathrm{a}$ & + \\
CM4 & $28.60 \pm 4.57 \mathrm{a}$ & $45 \pm 51.04 \mathrm{ab}+$ & + & $30 \pm 47.02 \mathrm{ab}$ & + \\
CM5 & $28.90 \pm 4.63 \mathrm{a}$ & $50 \pm 51.30 \mathrm{~b}$ & + & $25 \pm 44.43 \mathrm{a}$ & + \\
CM6 & $25.55 \pm 5.83 \mathrm{a}$ & $45 \pm 51.04 \mathrm{ab}+$ & + & $55 \pm 51.04 \mathrm{~b}$ & ++ \\
CM7 & $25.75 \pm 7.43 \mathrm{a}$ & $40 \pm 50.26 \mathrm{ab}+$ & $30 \pm 47.02 \mathrm{ab}$ & + \\
CM8 & $35.20 \pm 4.98 \mathrm{~b}$ & $35 \pm 48.94 \mathrm{a}$ & + & $20 \pm 41.04 \mathrm{a}$ & + \\
CM9 & $28.55 \pm 5.34 \mathrm{a}$ & $50 \pm 51.30 \mathrm{~b}$ & + & $20 \pm 41.04 \mathrm{a}$ & + \\
CM10 & $29.20 \pm 3.65 \mathrm{a}$ & $35 \pm 48.94 \mathrm{a}$ & + & $25 \pm 44.43 \mathrm{a}$ & + \\
CM11 & $28.25 \pm 6.08 \mathrm{a}$ & $40 \pm 50.26 \mathrm{ab}+$ & + & $20 \pm 41.04 \mathrm{a}$ & + \\
CM12 & & & + \\
\hline
\end{tabular}

Data are presented as mean \pm standard deviation. Data in the same column followed by different letters are significantly different at the $5 \%$ level of the Student-Newman-Keuls test. +, ++ and +++ refer to hyperhydricity and tissue browning intensities: +, low intensity; ++, moderate intensity; +++, high intensity.

The results of the present study showed that hyperhydricity ranged from 35 to $50 \%$ (Table 1). The highest hyperhydricity percentages were generally observed when MS/2 basal formulation was used (CM2, CM3, CM4 and CM6), except for CM10 medium, which was the only medium with MS/3 mineral salts that showed such high hyperhydricity rate. Our results showed that MS/2 resulted in an hyperhydricity rate ranging from 45 to $50 \%$, while the use of MS/3 basal formulation reduced the hyperhydricity rate to 35\% (CM9 and CM11 media). Regarding the intensity of hyperhydricity, all culture media evaluated in the present work showed low intensity.

Hyperhydricity is a morphological disorder reflected by translucent and vitreous tissues [27]. This phenomenon was observed by many researchers while in vitro propagating different plant species $[28,29]$ and is widely observed during the micropropagation of date palm [14, 30]. Hyperhydricity has been linked to many factors including the high ammonium concentration, some PGRs and the texture of culture medium $[9,14,20]$. In the present study, decreasing the concentration of culture medium mineral salts by using one-third-strength MS medium significantly reduced the incidence of hyperhydricity. This in good agreement with the results obtained in date palm cv. Al-Fayda. In fact, in this cultivar, the use of MS/2 medium resulted in a significantly lower frequency of hyperhydricity than full strength MS medium [9].

While evaluating the effects of PVP, activated charcoal and medium strength on hyperhydricity and tissue browning, we also assessed the impact of these factors on adventitious shoot bud multiplication. In fact, it is important to have a high multiplication rate of healthy and vigorous buds. The findings of the present study showed that the highest multiplication rate was observed on CM9 medium, with 35.2 adventitious shoot buds per explant (Fig. 1). This medium, which was supplemented with $1.5 \mathrm{~g} / \mathrm{L}$ activated charcoal, showed also the lowest rates of hyperhydricity (35\%) and 
tissue browning (20\%), and thus could be suggested for the multiplication of adventitious shoot buds of date palm cv. Aziza Bouzid. The highest multiplication rate reported by Elmaataoui et al. [17] was 26.9 shoot buds per explant. Accordingly, it could be concluded that the high hyperhydricity and tissue browning percentages observed by Elmaataoui et al. [17] are responsible for reducing the multiplication rate of adventitious shoot buds. Thus, the use 1.5 $\mathrm{g} / \mathrm{L}$ activated charcoal is strongly recommended for the multiplication of adventitious shoot buds of date palm cv. Aziza Bouzid. Comparing our results with those obtained in other date palm cultivars, we can clearly observe that cv. Aziza Bouzid has a high multiplication capacity. In fact, in date palm cv. Najda, the highest multiplication rate was 23.5 shoot buds per explant [13]. In cv. Boufeggous, the multiplication rate was 22.9 [14] while in cv. Mejhoul and Al-Fayda, the highest multiplication rates obtained were 18.7 and 30.0 shoot buds per explant, respectively $[9,15]$.

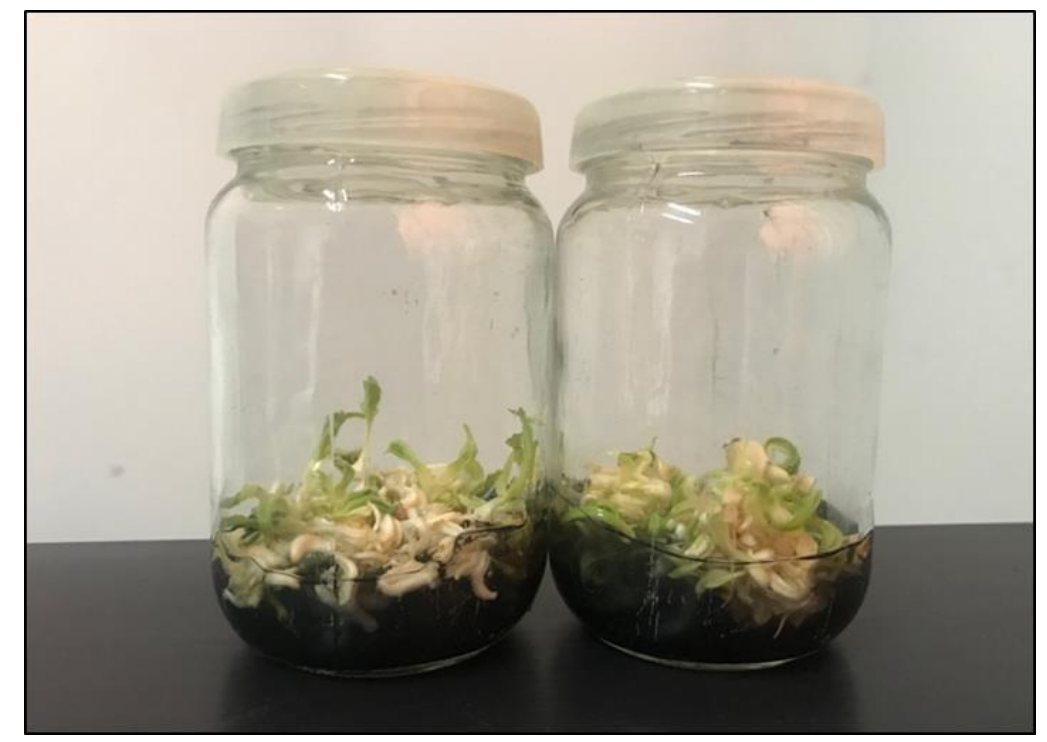

Figure 1 Adventitious shoot bud multiplication of date palm cv. Aziza Bouzid on MS/3 medium supplemented with 0.5 $\mathrm{mg} / \mathrm{L}$ NOA, $0.5 \mathrm{mg} / \mathrm{L}$ kinetin and $1.5 \mathrm{~g} / \mathrm{L}$ activated charcoal.

After transferring adventitious shoots to PGR-free MS/2 medium for elongation and rooting, normal growth and development was observed, and the regenerated plants showed high survival rates (80\%) after transferring them to ex vitro conditions.

\section{Conclusion}

As conclusion, we successfully reduced the incidence of tissue browning and hyperhydricity in date palm cv. Aziza Bouzid. The use of MS/3 medium containing $1.5 \mathrm{~g} / \mathrm{L}$ activated charcoal resulted in the lowest tissue browning and hyperhydricity frequencies as well as the highest rate of multiplication. Accordingly, MS/3 basal formulation and activated charcoal at the concentration of $1.5 \mathrm{~g} / \mathrm{L}$ are strongly suggested for rapid and efficient multiplication of date palm cv. Aziza Bouzid. We are currently evaluating the effects of different compounds and additives on shoot elongation and rooting, and subsequent acclimatization of plantlets of date palm cv. Aziza Bouzid.

\section{Compliance with ethical standards}

\section{Acknowledgments}

The present investigation was fully supported by the National Institute of Agronomic Research of Morocco.

\section{Disclosure of conflict of interest}

The authors declare no conflict of interest. 


\section{References}

[1] Al-Khayri JM, Naik PM, Jain SM and Johnson DV. (2018). Advances in date palm (Phoenix dactylifera L.) breeding. In: Al-Khayri JM, Jain SM, Johnson DV (eds) Advances in plant breeding strategies: fruits. Springer Nature, Switzerland, 727-771.

[2] Jaiti F, Meddich A and El Hadrami I. (2007). Effectiveness of arbuscular mycorrhizal fungi in the protection of date palm (Phoenix dactylifera L.) against bayoud disease. Physiol Mol Plant Pathol, 71, 166-173.

[3] Mazri MA, Meziani R, Belkoura I, Mokhless B and Nour S. (2018). A combined pathway of organogenesis and somatic embryogenesis for an efficient large-scale propagation in date palm (Phoenix dactylifera L.) cv. Mejhoul. 3Biotech, 8, 215.

[4] Mazri MA and Meziani R. (2015). Micropropagation of date palm: a review. Cell Dev Biol , 4(3), 160.

[5] Meziani R, Jaiti F, Mazri MA, Anjarne M, Ait Chitt M, El Fadile J and Alem C. (2015). Effects of plant growth regulators and light intensity on the micropropagation of date palm (Phoenix dactylifera L.) cv. Mejhoul. J Crop Sci Biotech, 18, 325-331.

[6] Meziani R, Jaiti F, Mazri MA, Hassani A, Ben Salem S, Anjarne M, Ait Chitt M and Alem C. (2016). Organogenesis of Phoenix dactylifera L. cv. Mejhoul: influences of natural and synthetic compounds on tissue browning, and analysis of protein concentrations and peroxidase activity in explants. Sci Hortic, 204, 145-152.

[7] Mazri MA, Belkoura I, Meziani R, Es-Saoudy H, Rachad F and Elmaataoui S. (2019). Impact of osmotica and plant growth regulators on somatic embryogenesis of date palm. Curr Agri Res J, 7(3), 296-303.

[8] Mazri MA, Meziani R, Belkoura I, Elmaataoui S, Mokhless B and Nour S. (2019). Maturation and germination of date palm (Phoenix dactylifera L.) somatic embryos. Not Sci Biol, 11, 86-93.

[9] Mazri MA, Meziani R, Elmaataoui S, Alfeddy MN and Jaiti F. (2019). Assessment of genetic fidelity, biochemical and physiological characteristics of in vitro grown date palm cv. Al-Fayda. Vegetos, 32, 333-344.

[10] Moghaieb REA, Abdel-Hadi AA and Ahmed MRA. (2011). Genetic stability among date palm plantlets regenerated from petiole explants. Afr J Biotechnol, 10, 14311-14318.

[11] Saker MM, Bekheet SA, Taha HS, Fahmy AS and Moursy HA. (2000). Detection of somaclonal variations in tissueculture derived date palm plants using isoenzyme analysis and RAPD fingerprints. Biol Plant, 43, 347-351.

[12] Saker MM, Adawy SS, Mohamed AA and El-Itriby HA. (2006). Monitoring of cultivar identity in tissue culturederived date palms using RAPD and AFLP analysis. Biol Plant, 50, 198-204.

[13] Mazri MA and Meziani R. (2013). An improved method for micropropagation and regeneration of date palm (Phoenix dactylifera L.). J Plant Biochem Biotechnol, 22, 176-184.

[14] Mazri MA. (2015). Role of cytokinins and physical state of the culture medium to improve in vitro shoot multiplication, rooting and acclimatization of date palm (Phoenix dactylifera L.) cv. Boufeggous. J Plant Biochem Biotechnol, 24, 268-275.

[15] Mazri MA, Meziani R, El Fadile J and Ezzinbi A. (2016). Optimization of medium composition for in vitro shoot proliferation and growth of date palm cv. Mejhoul. 3Biotech, 6, 111.

[16] Jain SM. (2012). Date palm biotechnology: current status and prospective-an overview. Emir J Food Agric, 24, 386-399.

[17] Elmaataoui S, Mazri MA, Meziani R, Bouchiha F, Anjarne M and Alfeddy MN. (2020). Optimization of auxincytokinin combination for rapid proliferation of adventitious buds of date palm cv. Aziza Bouzid. GSC Biol Pharm Sci, 11, 1-8.

[18] Abohatem M, Zouine J and El Hadrami I. (2011). Low concentrations of BAP and high rate of subcultures improve the establishment and multiplication of somatic embryos in date palm suspension cultures by limiting oxidative browning associated with high levels of total phenols and peroxidase activities. Sci Hortic, 130, 344-348.

[19] Loutfi K and El Hadrami I. (2005). Phoenix dactilyfera date palm. In: Litz RE (ed) Biotechnology of fruit and nut crops. CAB International, Wallingford, 144-156.

[20] Al-Khateeb AA. (2008).The problems facing the use of tissue culture technique in date palm (Phoenix dactylifera L.). Sci J King Faisal Univ, 9, 85-104. 
[21] Beauchesne G, Zaid A and Rhiss A. (1986). Meristematic potentialities of bottom of young leaves to rapidly propagate date palm. Proceedings second symposium on date palm. King Faisal University, Saudi Arabia, 87-94.

[22] Murashige T and Skoog FA. (1962). A revised medium for rapid growth and bioassays with tobacco tissue cultures. Phys Planta, 15, 473-479.

[23] Pan MJ and Van Staden J. (1998). The use of charcoal in in vitro culture-a review. Plant Growth Regul, 26, 155163.

[24] Wang QC, Laamanen J, Uosukainen M and Valkonen JPT. (2005). Cryopreservation of in vitro-grown shoot tips of raspberry (Rubus idaeus L.) by encapsulation-vitrification and encapsulation-dehydration. Plant Cell Rep, 24, 280-288.

[25] Guo YH, Bai JH and Zhang ZX. (2007). Plant regeneration from embryogenic suspension-derived protoplasts of ginger (Zingiber officinale Rosc.). Plant Cell Tissue Org Cult, 89, 151-157.

[26] Babaei N, Abdullah NA, Saleh G and Abdullah TL. (2013). Control of contamination and explant browning in Curculigo latifolia in vitro cultures. J Med Plant Res, 7, 448-454.

[27] Debergh P, Aitken-Chistie J, Cohen D, Grout B, Von Arnold S, Zimmermann TW and Ziv M. (1992). Reconsideration of the term vitrification as used in micropropagation. Plant Cell Tissue Org Cult, 30, 135-140.

[28] Barakat MN and El-Sammak H. (2011). In vitro culture and plant regeneration from shoot tip and lateral bud explants of Gypsophila paniculata L. J Med Plant Res, 5, 3351-3358.

[29] Badr-Elden AM, Nower AA, Ibrahim IA, Ebrahim MKH and AbdElaziem TM. (2012). Minimizing the hyperhydricity associated with in vitro growth and development of watermelon by modifying the culture conditions. Afr J Biotechnol, 11, 8705-8717.

[30] McCubbin MJ and Zaid A. (2007). Would a combination of organogenesis and embryogenesis techniques in date palm micropropagation be the Answer? Acta Hortic, 736, 255-259.

\section{How to cite this article}

Elmaataoui S, Mazri MA, Meziani R and Bouchiha F. (2020). Effects of culture medium strength and antioxidants on adventitious bud multiplication, hyperhydricity and tissue browning of date palm cv. Aziza Bouzid. World Journal of Advanced Research and Reviews, 6(2), 103-109. 